\title{
AGGRESSION AND CYBERBULLYING OF PUPILS IN SLOVAK REPUBLIC
}

\author{
[AGRESIA A KYBERAGRESIA ŽIAKOV V SLOVENSKEJ \\ REPUBLIKE]
}

Katarina Holla

DOI: 10.18355/PG.2015.4.1.50-61

\begin{abstract}
The work brings and synthesizes brand new findings related to the influence of new media and child behaviour. The attention is focused on the aggressive behaviour in adolescents, which currently has an increasing tendency. Special attention is devoted to new forms of aggressive behaviour in children cyberbullying. Understanding this socio-pathological phenomenon and its comparison with traditional forms of aggression became the object of our study. This paper studies the correlation between aggression and cyberaggression. It provides results of a research among pupils $(\mathrm{N}=400)$ in Slovakia which focused on aggression and tolerance of cyberaggression. Sexdisaggregated statistical data show the same level of aggression in both boys and girls. A significant geography-related difference has been proven when studying aggressive inclination in pupils coming from different regions. A natural relationship between aggression and cyberaggression has been confirmed. Pupils displaying high levels of aggression, at the same time showed high levels of tolerance for cyberaggression.

The increased rate of tolerance for cyber bullying is perceived as the consequence of not determining the rules and insufficient control over the use of the media in family environment.
\end{abstract}

\section{Key words}

aggression, cyberaggression, cyberbullying, research

\section{Anotácia}

Práca prináša a syntetizuje najnovšie poznatky ohl'adom pôsobenia nových médií a správania sa diet’at'a. Pozornost' sústred'ujeme na agresívne správanie sa dorastajúcich, ktoré má v súčasnosti vzostupnú tendenciu. Osobitnú pozornost' venujeme novým formám agresívneho správania sa detí kyberšikane. Objektom nášho skúmania je objasnenie tohto sociálnopatologického javu a jeho komparácia s tradičnou agresiou. Štúdia skúma kolerácie agresie a kyberagresie. Prináša výsledky výskumu žiakov $(\mathrm{N}=400)$ zo Slovenskej republiky zamerané na agresiu a toleranciu kyberagresie. Z hl'adiska pohlavia vykazovali chlapci ako aj dievčatá štatisticky rovnaké výsledky miery agresie. Signifikantne významný rozdiel sa preukázal pri skúmaní agresívnej výbavy žiakov vzhl'adom ku kraju, z ktorého pochádzali. Potvrdila sa zákonitost' agresie a kyberagresie. Žiaci, ktorí mali vysokú mieru agresie, zároveň vykazovali vysokú mieru tolerancie voči kyberagresii. 
Zvýšenú mieru tolerancie kyberšikany vnímame ako následok nestanovenia pravidiel a nedostatočnej kontroly používania médií v rodinnom prostredí.

\section{Kl’účové slová}

agresia, kyberagresia, kyberšikana, výskum

\section{Úvod}

V súčasnej dobe je samozrejmé používanie technológií. Komunikačné prostriedky majú mnoho potenciálnych výhod. Obzvlášt' prínosné sú pre mladých l'udí, ktorým umožňujú rozvíjat' vzt’ahy s inými osobami. Podporujú online socializáciu u tých dospievajúcich, ktorí majú t'ažkosti rozvíjat' priatel'stvá $\mathrm{v}$ tradičných spoločenských prostrediach, alebo majú obmedzené kontakty s osobami rovnakého veku. Okrem toho pravidelný prístup $\mathrm{k}$ internetu umožňuje mladým l'ud'om, aby promptne zvýšili svoje vedomosti $\mathrm{v}$ extenzívnych oblastiach society 21 . storočia.

Napriek množstvu výhod, ktoré ponúkajú masovokomunikačné prostriedky, ich expanzia do rôznych oblasti l'udskej činnosti prináša aj isté riziká. Zvyšuje sa počet prípadov týkajúcich sa zneužívania médií pre agresívne činy. V dôsledku rozvoja informačných technológií a informatizácie spoločnosti, možno badat' presun agresie do kyberpriestoru. V súčasnosti existuje málo výskumov zameraných na zistenie vzt’ahu medzi agresiou a online agresiou. Štúdia približuje kolerácie agresie a online agresie u žiakov nižšieho sekundárneho vzdelávania, čím rozširuje výskumy v danej oblasti.

\section{Prehl'ad agresie a kyberagresie v teoretických a empirických východiskách}

Problematike agresie a agresívneho správania sa venuje vel'ká pozornost' zo strany takmer všetkých vedných disciplín, ktoré sa zaoberajú správaním jednotlivca, jeho životom v sociálnych skupinách a celej spoločnosti. Zvlášt' sa upozorňuje na nárast agresivity medzi det'mi a mládežou. Agresiou je spravidla označované správanie, ktorého zámerom je poškodit' obet', ublížit', ponížit', alebo spôsobit’ inú fyzickú, psychickú a emocionálnu ujmu (Rican, 1999, Lovas, 2010, Ondrejkovic, 2009). Teoretický základ skúmania danej problematiky prinášajú odborné štúdie a výskumy zamerané na agresiu, ako aj oblast' šikanovania, ktoré v posledných rokoch realizovali: Z. Martínek (2009), P. Rican a P. Janosova (2010), M. Adamik - Simegova (2011), Z. Hrivikova (2013), K. Holla (2013). Nedávne výskumy upozornili na nárast verbálnej agresie žiakov a fyzických útokov dievčat (Holla - Kurincova, 2013). Teoreticko-empirická platforma prináša zistenia ohl'adom agresívnych prejavov žiakov, psychologických aspektov šikanovania, ako aj nových foriem agresie - predovšetkým kyberšikany u žiakov. V posledných rokoch sa pozornost' odborníkov upriamuje na relačnú a sociálnu agresiu dievčat, prejavovanú v medzil'udských osobných vzt'ahoch, ako aj v kyberprostredí.

Vedci, ktorí sa zaoberajú skúmaním agresívneho správania v online prostredí, používajú termín kyberagresia častejšie ako násilie. Pojem agresie, ktorá sa objavuje v online prostredí, nie je jasne definovaný. Definícia kyberagresie vychádza z agresie, ktorou je akékol’vek zámerné negatívne správanie, 
ktorého intenciou je poškodenie, doplnená je však o prostriedky masovej komunikácie, ktoré slúžia k realizovaniu agresívnych kyberútokov.

C. L. Schoffstall a R. Cohen (2011, s. 588) charakterizujú kybernetickú agresiu ako úmyselné konanie, ktorého ciel'om je poškodit' inú osobu alebo osoby, pomocou počítačov, mobilných telefónov a iných elektronických zariadení. Kyberagresia je termín, ktorý zachytáva všetky typy násilia, ktoré sa vyskytujú v kybeprostredí, vrátane obt’ažovania a ohrozovania, vydierania, prenasledovania, kyberšikany a iných. Vel'mi často sa kyberagresia spája s kyberšikanou, preto považujeme za potrebné zduplikovat' nadradený pojem kyberagresie nad kyberšikanou. Kyberšikanu definujú M. Välimäki et al. (2012) ako šikanovanie a obt’ažovanie druhých prostredníctvom nových elektronických technológií, najmä mobilných telefónov a internetu. Kyberšikanu explikujeme ako agresívne správanie, ktoré zahŕňa sužovanie, ohrozovanie, prenasledovanie, ponižovanie a iné negatívne správanie diet’at'a alebo dospievajúceho voči obeti alebo obetiam, a to prostredníctvom opakovaných útokov cez počítač, mobil a iné elektronické zariadenia, ktorých obsah spôsobuje emocionálnu ujmu (Holla, 2013).

Výskumné šetrenia zamerané na zist'ovanie vzt'ahu medzi agresiou a kyberagresiou, prípadne kyberšikanovaním sú ojedinelé. Zo zahraničných výskumov spomenieme výskum Ch. D. Pornariovej a J. Woodovej (2009), ktoré skúmali vzt’ah medzi kognitívnymi mechanizmami použitými pri racionalizácii jednotlivých zákazov, morálkou a zapojením sa do tradičnej rovesníckej agresie a kybernetickej agresie. Výskum bol realizovaný na vzorke 339 žiakov stredných škôl. Preukázalo sa, že celkové skóre spustenia morálky súvisí s oboma formami riadenej agresie. Pre potreby štúdie má význam zistenie, že kyberagresia a kyberprenasledovanie boli spojené s vysokou úrovňou tradičnej agresie a prenasledovania.

$\mathrm{Na}$ Slovensku boli realizované dve výskumné šetrenia zamerané na predmetnú problematiku. Prvý výskum prebiehal v roku 2009 a bol zameraný na zistenie miery korelácie agresie a tolerancie voči kyberšikane. Výskumu sa zúčastnilo 446 žiakov 8. a 9. ročníkov (52,2 \% chlapcov a 47,7 \% dievčat). Prostredníctvom Spearmanovho koeficienta poradovej korelácie R \& 0,6255 sa preukázal významný stupeň väzby medzi agresiou a toleranciou voči kyberšikane. Žiaci so zvýšenou predispozíciou správat' sa agresívne prejavovali aj vyššiu mieru tolerancie kyberšikany (Holla - Kurincova, 2013). Podobný výskum prebiehal v roku 2013 a bol zameraný na agresorov šikanovania $\mathrm{v}$ sociálnom prostredí a ich toleranciu online násilia. Zo štatistických metód bol využitý dvojvýberový F-test a dvojvýberový T-test, kde $\mathrm{T}$ (stat) $\mathrm{v}$ absolútnej hodnote pri týchto dvoch veličinách nadobudol hodnotu 2,430398696 a T (krit) 2,007583728. Ich porovnaním sa preukázalo, že miera akceptácie kyberšikany je významne vyššia u žiakov, ktorí sa už šikany dopustili, na rozdiel od tých, ktorí nešikanovali (Krascenicova, 2014).

\section{Metodologické východiská agresie a kyberagresie}

\section{Ciel' a predmet výskumu}

Nedostatok štúdií zaoberajúcich sa koleráciou agresie a kyberagresie nás viedol k revidovaniu danej problematiky. Kyberšikana a kyberagresia 
spoločne s rozmanitými agresívnymi prejavmi sú v súčasnosti aktuálnymi fenoménmi našej spoločnosti, vrátane školstva.

Ciel'om štúdie bolo zistit' vzt'ah medzi agresívnym správaním sa žiakov nižšieho sekundárneho vzdelávania a toleranciou voči kyberagresii. Z ciel'a vyplynuli nasledujúce úlohy:

1. zistit' vzt'ah medzi agresiou a pohlavím,

2. zistit' vzt'ah medzi agresiu a jednotlivými krajmi,

3. zistit' vzt'ah medzi agresiou a kyberagresiou,

4. komparovat’ zistenia s údajmi získanými v roku 2009.

\section{Výskumné metódy a meracie techniky}

Výskumné zistenia boli overované prostredníctvom dotazníka BPAQ, ktorý predstavuje štandardizovaný výskumný nástroj na meranie agresivity. Z hl'adiska psychometrických vlastností sa pre tento výskumný nástroj uvádza Cronbachov koeficient alfa pre celkové skóre agresivity 0,89 . Testretestová reliabilita bola realizovaná $\mathrm{v}$ priebehu 9 týždňov a jej hodnota dosiahla 0,80 (Buss - Perry, 1992). Dotazník agresivity BPAQ je výskumný nástroj s 29 položkami, ktorý na 5 bodovej Likertovej škále meria štyri druhy agresívneho správania - verbálnu agresivitu, fyzickú agresivitu, zlost' a hostilitu.

Ďalším výskumným nástrojom bol Dotazník tolerancie online agresie. Jednotlivé položky dotazníka tolerancie merali agresívne správanie žiakov a online agresiu.

Zo štatistických metód pre analýzu metrických dát bol zvolený Pearsonov korelačný koeficient (r), ktorý predstavuje najdôležitejšiu mieru sily vzt'ahov dvoch náhodných premenných. Pearsonov korelačný koeficient nadobúda hodnoty od 0 do 1 , kde 0 predstavuje žiadny vzt'ah a 1 ideálny vzt'ah. Pri interpretovaní sme vychádzali z korelácie, kde pod 0,1 je triviálna, $0,1-0,3$ je malá, 0,3 - 0,5 je stredná a nad 0,5 vel'ká. Pozitívny výsledok vypovedá o tom, že vyšším hodnotám jednej premennej zodpovedajú vyššie hodnoty druhej premennej a naopak. V rámci štatistických metód sme pri analýze rozptylu použili test ANOVA a pre testovanie rozdielov dvoch rozptylov Ftest a Studentov T-test pre testovanie rozdielov dvoch stredných hodnôt. Pre overenie závislosti štatistických znakov bol použitý Test nezávislosti. Na testovanie kontrastov bol použitý Scheffeho a Turkey-ov test.

\section{Výskumná vzorka}

Skúmanou populáciou boli žiaci II. stupňa základných škôl (žiaci nižšieho sekundárneho vzdelávania). Dôvodom výberu respondentov 8. a 9. ročníkov bola skutočnost', že deti v tomto vývinovom období hl'adajú identitu i prostredníctvom mediálnych vzorov. Uvedenú vekovú skupinu možno označit' pojmom e-generácia, t j. mladí l'udia vyrastajúci s prostriedkami informačno-komunikačných technológií, ktorí dokážu využívat' potenciál nových médií. Jednotlivci boli z populácie vybraní na základe stratifikovanej dostupnosti. Výskumu sa zúčastnilo 400 respondentov (SD 1,41), z toho 235 dievčat $(58,75 \%$, SD 1,41) a 165 chlapcov $(41,25 \%$, SD 1,43). 
Agresia žiakov z hl'adiska pohlavia

Agresívne správanie žiakov bolo skúmané prostredníctvom dotazníka BPAQ (Buss - Perry, 1991). Intenciou štúdie nie je analýza jednotlivých komponentov agresie, sústredili sme sa na agresiu ako celok, bez ohl'adu na jej formy, ktoré dotazník BPAQ skúma. Agresia sa u dievčat preukázala takmer v $69 \%$ a u chlapcov v $71 \%$. Rozptyl u dievčat predstavoval hodnotu 241,814 a u chlapcov 255,833 .

Tab. 1 Základné charakteristiky

\begin{tabular}{|c|c|c|}
\hline \multicolumn{3}{|c|}{ ZÁKLADNÉ CHARAKTERISTIKY } \\
\hline & dievčatá & chlapci \\
\hline Priemer & 68,689 & 70,855 \\
\hline Rozptyl & 241,814 & 255,833 \\
\hline
\end{tabular}

Porovnaním stredných hodnôt (priemerov) obsiahnutých v tabul'ke sa ukazuje vyššia miera agresie u chlapcov. Štatistickým spracovaním údajov prostredníctvom porovnania rozptylov (F-test) sme dosiahli hodnotu testovacieho kritéria $F=1,059897$. Ked'že hodnota testovacieho kritéria vyšla nižšia ako oficiálne daná hodnota kritéria, nepreukázal sa medzi rozptylmi štatisticky významný rozdiel.

Tab. 2 F-test dvoch rozptylov

\begin{tabular}{|l|r|r|}
\hline & \multicolumn{1}{|c|}{ Dievčatá } & \multicolumn{1}{c|}{ Chlapci } \\
\hline Priemer & 70,85455 & 68,68936 \\
\hline Rozptyl & 257,3933 & 242,8475 \\
\hline Počet & 165 & 235 \\
\hline df & 164 & 234 \\
\hline F & $\mathbf{1 , 0 5 9 8 9 7}$ & \\
\hline P(F $<=$ f $)$ & 0,339984 & \\
\hline F Critical & $\mathbf{1 , 2 6 4 4 2 8}$ & \\
\hline
\end{tabular}

Na porovnanie stredných hodnôt sme použili T-test. Prostredníctvom T-testu sme dosiahli hodnotu testovacieho kritéria t 1,351386 nižšiu ako je hodnota daná tabul'kami. 
Tab. 3. T-test dvoch stredných hodnôt

\begin{tabular}{|l|r|r|}
\hline & \multicolumn{1}{|c|}{ Dievčatá } & \multicolumn{1}{c|}{ Chlapci } \\
\hline Priemer & 70,85455 & 68,68936 \\
\hline Rozptyl & 257,3933 & 242,8475 \\
\hline Početnost' & 165 & 235 \\
\hline Pooled Variance & 248,8413 & \\
\hline df & 398 & \\
\hline t Stat & $\mathbf{1 , 3 5 1 3 8 6}$ & \\
\hline P(T<=t) one tail & 0,08867 & \\
\hline t Critical one tail & 1,648691 & \\
\hline P(T<=t) two-tail & 0,177339 & \\
\hline t Critical two-tail & $\mathbf{1 , 9 6 5 9 4 2}$ & \\
\hline
\end{tabular}

Oba testy boli realizované na hladine významnosti alfa $=0,05$. Významný štatistický ukazovatel' medzi pohlavím a agresiou sa nepreukázal. Chlapci, rovnako ako dievčatá vykazovali štatisticky rovnaké výsledky.

Agresia žiakov podl'a jednotlivých krajov

V d'alšom kroku sme zist'ovali vzt'ah medzi dvomi premennými, agresiou žiakov a krajom. Koeficient korelácie predstavoval hodnotu -0,02086, pri počte 400 meraní počet stupňov vol'nosti $(n-2) 398$ a testovacie kritérium T $-0,41621$. Na hladine významnosti 0,05 sme prijali tvrdenie o nezávislosti jednotlivých veličín.

Tab. 4 Ukazovatele agresie podl'a krajov

\begin{tabular}{|l|r|r|r|r|r|}
\hline \multicolumn{1}{|c|}{ Kraj } & \multicolumn{1}{c|}{ Počet } & \multicolumn{1}{c|}{ Súčet } & \multicolumn{1}{c|}{ Priemer } & \multicolumn{1}{c|}{ Rozptyl } & Odchýlka \\
\hline Žilinský kraj & 50 & 3380 & 67,6 & 237 & 241,8367 \\
\hline Trnavský kraj & 50 & 3483 & 69,66 & 173,5 & 177,0453 \\
\hline $\begin{array}{l}\text { Banskobystrický } \\
\text { kraj }\end{array}$ & 50 & 3661 & 73,22 & 284,21 & 290,0118 \\
\hline Prešovský kraj & 50 & 3661 & 73,22 & 230,41 & 235,1139 \\
\hline Bratislavský kraj & 50 & 3334 & 66,68 & 299,94 & 234,6302 \\
\hline Košický kraj & 50 & 3495 & 69,9 & 431,53 & 440,3367 \\
\hline Trenčiansky kraj & 50 & 3218 & 64,36 & 121,5 & 123,9494 \\
\hline Nitriansky kraj & 50 & 3601 & 72,02 & 209,7 & 213,9384 \\
\hline
\end{tabular}


Stredné hodnoty agresie, ako aj rozptyly v jednotlivých krajoch sa nejavia štatisticky rovnaké. Niektoré kraje vykazujú vyššie priemery. Ako vyplýva z výsledkov, v banskobystrickom a prešovskom kraji žiaci zhodne vykazujú vyššiu mieru agresie ako v trenčianskom kraji. K podrobnejšej analýze a na porovnanie stredných hodnôt viacerých výberov sme použili test ANOVA.

Tab. 5 Test ANOVA

\begin{tabular}{|l|c|c|c|c|c|c|}
\hline ANOVA & $\boldsymbol{S S}$ & $\boldsymbol{d} \boldsymbol{f}$ & $\boldsymbol{M S}$ & $\boldsymbol{F}$ & $\begin{array}{c}\boldsymbol{P} \text { - } \\
\text { value }\end{array}$ & $\boldsymbol{F}$ crit \\
\hline Source of Variation & 3607,02 & 7 & 515,28 & 2,11 & 0,04 & 2,03 \\
\hline Between Groups & 95886,3 & 392 & 244,61 & & & \\
\hline Within Groups & 99493,3 & 399 & & & & \\
\hline Total & & & & & \\
\hline
\end{tabular}

Test ANOVA preukázal, že dva náhodné výbery nemajú rovnaké stredné hodnoty. Preukázali sa významné rozdiely medzi vybranými priemermi. Pri porovnávaní dvojíc náhodných výberov sme skúmali rozdiely priemerov banskobystrického a trenčianskeho kraja prostredníctvom F-testu a T-testu (údaje v tabul'ke 6 a 7).

Tab. 6 F-test rozptylov

\begin{tabular}{|l|r|r|}
\hline & \multicolumn{1}{|c|}{$\boldsymbol{B B}$} & \multicolumn{1}{|c|}{$\boldsymbol{T N}$} \\
\hline Priemer & 73,22 & 64,36 \\
\hline Rozptyl & 290,0118 & 123,9494 \\
\hline Početnost' & 50 & 50 \\
\hline df & 49 & 49 \\
\hline F & 2,33976 & \\
\hline P(F<=f) one-tail & 0,001765 & \\
\hline F Critical one-tail & 1,607289 & \\
\hline
\end{tabular}

Tab. 7 T-test stredných hodnôt

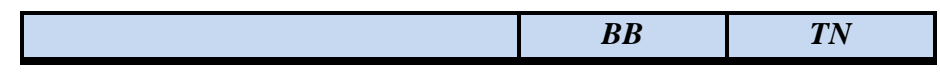




\begin{tabular}{|l|r|r|}
\hline Priemer & 73,22 & 64,36 \\
\hline Rozptyl & 290,0118 & 123,9494 \\
\hline Početnost' & 50 & 50 \\
\hline Hypothesized Mean Diff. & 0 & \\
\hline df & 84 & \\
\hline t Stat & 3,079207 & \\
\hline P(T<=t) one-tail & 0,001402 & \\
\hline t Critical one-tail & 1,663197 & \\
\hline $\mathbf{P}(\mathbf{T}<=t)$ two-tail & 0,002804 & \\
\hline t Critical two-tail & 1,98861 & \\
\hline
\end{tabular}

Ako vidiet'

z výsledko

v, žiaci

banskobyst

rického

kraja

vykazujú

štatisticky

vyššiu

mieru

agresie ako žiaci

trenčianskeho kraja (a odhadom rovnakú ako v prešovskom kraji). Hoci sa priamu závislost' medzi krajom a agresiou podarilo vylúčit' pomocou koeficientu korelácie, možno pozorovat' rozdiely medzi dosiahnutou mierou agresie, pričom tieto rozdiely nie sú štatisticky zanedbatel'né. Bližšie ukazovatele o rozdieloch v agresii podl'a krajov sme dosiahli prostredníctvom Testu kontrastov (Scheffeho test - S metóda) podl'a vzorca:

$$
\left|x_{i \bullet}-x_{j \bullet}\right|>\sqrt{\left(\frac{1}{n_{i}}+\frac{1}{n_{j}}\right) \cdot(m-1) \cdot s_{r}^{2} \cdot F_{\alpha}(m-1, n-m)}
$$

Kritická hodnota bola 11, 80. Prostredníctvom Scheffehovho testu sa preukázal rozdiel v agresii žiakov v jednotlivých krajoch.

Tab. 8 Rozdiely agresie žiakov $v$ jednotlivých krajoch

\begin{tabular}{|c|c|c|c|c|c|c|c|c|c|c|c|c|c|}
\hline $\mathrm{TT}$ & 2,06 & & & & & & & & & & & & \\
\hline BB & $\begin{array}{c}- \\
5,62\end{array}$ & $\begin{array}{c}\text { TT } \\
- \\
\text { BB }\end{array}$ & $\overline{3,56}$ & & & & & & & & & & \\
\hline $\mathrm{PO}$ & $\begin{array}{c}- \\
5,62\end{array}$ & $\begin{array}{c}\text { TT } \\
- \\
\text { PO }\end{array}$ & $\overline{3,56}$ & $\begin{array}{c}\text { BB } \\
- \\
\text { PO }\end{array}$ & 0 & & & & & & & & \\
\hline BA & 0,92 & $\begin{array}{c}\text { TT } \\
- \\
\text { BA }\end{array}$ & 2,98 & $\begin{array}{c}\text { BB } \\
- \\
\text { BA }\end{array}$ & 6,54 & $\begin{array}{c}\mathrm{PO} \\
- \\
\mathrm{BA}\end{array}$ & 6,54 & & & & & & \\
\hline $\mathrm{KE}$ & $-2,3$ & $\begin{array}{c}\mathrm{TT} \\
- \\
\mathrm{KE}\end{array}$ & - & $\begin{array}{c}\mathrm{BB} \\
- \\
\mathrm{KE}\end{array}$ & 3,32 & $\begin{array}{c}\mathrm{PO} \\
- \\
\mathrm{KE}\end{array}$ & 3,32 & $\begin{array}{c}\mathrm{BA} \\
- \\
\mathrm{KE}\end{array}$ & - & & & & \\
\hline $\mathrm{TN}$ & 3,24 & $\begin{array}{c}\text { TT } \\
- \\
\text { TN }\end{array}$ & 5,3 & $\begin{array}{c}\text { BB } \\
- \\
\text { TN }\end{array}$ & 8,86 & $\begin{array}{c}\mathrm{PO} \\
- \\
\mathrm{TN}\end{array}$ & 8,86 & $\begin{array}{c}\text { BA } \\
- \\
\text { TN }\end{array}$ & 2,32 & $\begin{array}{c}\mathrm{KE} \\
- \\
\mathrm{TN}\end{array}$ & 5,54 & & \\
\hline NR & - & $\begin{array}{c}\mathrm{TT} \\
- \\
\mathrm{NR}\end{array}$ & - & $\begin{array}{c}\mathrm{BB} \\
- \\
\mathrm{NR}\end{array}$ & 1,2 & $\begin{array}{c}\mathrm{PO} \\
- \\
\mathrm{NR}\end{array}$ & 1,2 & $\begin{array}{c}\text { BA } \\
- \\
\text { NR }\end{array}$ & - & $\begin{array}{c}\mathrm{KE} \\
- \\
\mathrm{NR}\end{array}$ & - & $\begin{array}{c}\mathrm{TN} \\
- \\
\mathrm{NR}\end{array}$ & $\begin{array}{c}- \\
7,66\end{array}$ \\
\hline
\end{tabular}


Jednotlivé ukazovatele boli podrobené d'alšiemu štatistickému spracovaniu prostredníctvom Turkey-ovho testu (T-metóda) a dosadené do vzorca:

$$
\left|x_{i \bullet}-x_{j \bullet}\right|>T . s_{r} \quad T=\frac{1}{\sqrt{N}} \cdot q_{\alpha(m, n-m)}
$$

Pre hladinu významnosti alfa 0,05 bola nameraná hodnota $\mathrm{q}=4,286, \mathrm{~T}=$ 0,2143 a kritická hodnota 3,3516. Pre alfa 0,01 bola zistená hodnota $\mathrm{q}=$ $4,987, T=0,2494$ a kritická hodnota 3,8998. Štatisticky významný rozdiel sa ukázal vo vyššej miere agresie žiakov trnavského kraja na rozdiel od žiakov z banskobystrického a prešovského kraja. Štatisticky vysoko signifikantný rozdiel sa preukázal vo vyššej miere agresívneho správania žiakov trnavského kraja oproti žiakom trenčianskeho kraja, u žiakov banskobystrického kraja oproti žiakom bratislavského a trenčianskeho kraja, u žiakov prešovského kraja oproti žiakom bratislavského a trenčianskeho kraja, u žiakov košického kraja v porovnaní so žiakmi trenčianskeho kraja.

\section{Agresia a kyberagresia žiakov a komparácia s rokom 2009}

V d’alšom kroku sme koeficientom korelácie zist'ovali mieru vzt'ahu agresie a kyberagresie žiakov. Získali sme hodnotu koeficientu korelácie $\mathrm{r}=0,522$ a testovacie kritérium $\mathrm{T}=12,199$. $\mathrm{V}$ tomto prípade koeficient korelácie predstavoval vysokú závislost'. Z uvedeného vyplýva, že medzi agresiou a kyberagresiou sa preukázala závislost'.

Napokon sme získané údaje korelovali vzhl’adom k škole, pohlaviu a výskumu realizovanom v roku 2009. V roku 2009 sa výskumu zúčastnilo 446 žiakov základných škôl, v danom roku korelačný koeficient predstavoval hodnotu 0,668 , čo značí vysokú mieru korelácie a významný štatistický ukazovatel'. V roku 2014 sa výskumu zúčastnilo 400 žiakov a koeficient korelácie dosiahol už spomínanú hodnotu 0,522 , ktorú Cohen radí medzi vysokú koreláciu. Spojením empirických dát získaných $\mathrm{v}$ jednotlivých rokoch u žiakov základných škôl (n 846) sme dosiahli korelačný koeficient 0,610 - vysoká korelácia.

Tab. 9 Ukazovatele korelačného koeficientu podl’a rokov výskumu

\begin{tabular}{|c|c|c|c|c|c|c|c|}
\hline \multirow{2}{*}{\multicolumn{2}{|c|}{ Ukazovatele }} & \multicolumn{2}{|c|}{ ZŠ 2009} & \multicolumn{2}{|c|}{ ZŠ 2014} & \multicolumn{2}{|c|}{ Spolu } \\
\hline & & $\begin{array}{c}\text { agresi } \\
\text { a }\end{array}$ & $\begin{array}{c}\text { kyber } \\
\text { agresi } \\
\text { a }\end{array}$ & $\begin{array}{c}\text { agresi } \\
\text { a }\end{array}$ & $\begin{array}{c}\text { kyber } \\
\text { agresi } \\
\text { a }\end{array}$ & $\begin{array}{c}\text { Agresi } \\
\text { a }\end{array}$ & $\begin{array}{c}\text { kyber } \\
\text { agresi } \\
\text { a }\end{array}$ \\
\hline \multirow{3}{*}{ agresia } & $\mathrm{r}$ & 1 & $668^{* * * *}$ & 1 &, $522^{* * * *}$ & 1 &, $610^{* * * *}$ \\
\hline & $\mathrm{p}$ & &, 000 & &, 000 & &, 000 \\
\hline & $\mathrm{n}$ & 446 & 444 & 400 & 400 & 846 & 844 \\
\hline \multirow{3}{*}{$\begin{array}{l}\text { kyber - } \\
\text { agresia }\end{array}$} & $\mathrm{r}$ & $668^{* * * *}$ & 1 &, $522^{* * * *}$ & 1 &, $610^{* * * *}$ & 1 \\
\hline & $\mathrm{p}$ &, 000 & &, 000 & &, 000 & \\
\hline & $\mathrm{n}$ & 444 & 444 & 400 & 400 & 844 & 844 \\
\hline
\end{tabular}


Tab. 10 Ukazovatele korelačného koeficientu podl'a rokov a ženského pohlavia

\begin{tabular}{|c|c|c|c|c|c|c|c|}
\hline \multirow{2}{*}{\multicolumn{2}{|c|}{ Ukazovatele }} & \multicolumn{2}{|c|}{ ZŠ 2009 dievčatá } & \multicolumn{2}{|c|}{ ZŠ 2014 dievčatá } & \multicolumn{2}{|c|}{ ZŠ dievčatá spolu } \\
\hline & & \multirow{2}{*}{$\begin{array}{r}\text { agresia } \\
1\end{array}$} & \multirow{2}{*}{$\begin{array}{c}\begin{array}{c}\text { kyber } \\
\text { agresia }\end{array} \\
, 680^{* * *}\end{array}$} & \multirow{2}{*}{$\begin{array}{r}\text { agresia } \\
1\end{array}$} & \multirow{2}{*}{$\begin{array}{c}\begin{array}{c}\text { kyber } \\
\text { agresia }\end{array} \\
, 530^{* * *}\end{array}$} & \multirow{2}{*}{$\begin{array}{r}\text { agresia } \\
1\end{array}$} & \multirow{2}{*}{$\begin{array}{c}\text { kyber } \\
\text { agresi } \\
\text { a } \\
, 625^{* * * *} \\
\end{array}$} \\
\hline \multirow{3}{*}{ agresia } & $\mathrm{r}$ & & & & & & \\
\hline & $\mathrm{p}$ & &, 000 & &, 000 & &, 000 \\
\hline & $\mathrm{n}$ & 233 & 232 & 235 & 235 & 468 & 467 \\
\hline \multirow{3}{*}{$\begin{array}{l}\text { kyber - } \\
\text { agresia }\end{array}$} & $\mathrm{r}$ &, $680^{* * * *}$ & 1 & $530^{* * *}$ & 1 &, $625^{* * *}$ & 1 \\
\hline & $\mathrm{p}$ &, 000 & & ,000 & &, 000 & \\
\hline & $\mathrm{n}$ & 232 & 232 & 235 & 235 & 467 & 467 \\
\hline
\end{tabular}

Vzt’ah medzi skóre agresie a skóre tolerancie je silný tak v roku 2009 ako aj $\mathrm{v}$ roku 2014. Z uvedeného vyplýva, že medzi agresiou a kyberšikanou existuje silný vzt’ah, ktorý nie je produktom náhody. Existuje zákonitost', že pri vysokej miere agresie vzrastá aj kyberagresia. Uvedená premisa sa potvrdila nielen na celom súbore, ale aj komparáciou údajov z hl'adiska pohlavia.

Pri analyzovaní korelácie agresie a kyberagresie u dievčat sme pracovali s dvomi súbormi. V roku 2009 výskumnú vzorku tvorilo 232 dievčat. Korelačný koeficient bol vyrátaný na 0,680 , čo predstavuje vel'mi silnú väzbu medzi premennými. V roku 2014 sa výskumu zúčastnil takmer rovnaký počet dievčat (n 235), koeficient bol nižší $(r=0,530)$, napriek tomu poukazoval na vysokú koreláciu. Sumárne pri počte 468 dievčat dosiahol koeficient hodnotu r 0,625, ide o vysokú koreláciu.

Tab. 11 Ukazovatele korelačného koeficientu podl’a rokov a mužského pohlavia

\begin{tabular}{|c|c|c|c|c|c|c|c|}
\hline \multirow{2}{*}{\multicolumn{2}{|c|}{ Ukazovatele }} & \multicolumn{2}{|c|}{ ZŠ 2009 chlapci } & \multicolumn{2}{|c|}{ ZŠ 2014 chlapci } & \multicolumn{2}{|c|}{ ZŠ chlapci spolu } \\
\hline & & \multirow{2}{*}{$\begin{array}{r}\text { agresia } \\
1\end{array}$} & \multirow{2}{*}{ 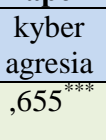 } & \multirow{2}{*}{$\begin{array}{r}\text { agresia } \\
1\end{array}$} & \multirow{2}{*}{$\begin{array}{c}\begin{array}{c}\text { kyber } \\
\text { agresia }\end{array} \\
, 503^{* * * *}\end{array}$} & \multirow{2}{*}{$\begin{array}{r}\text { agresia } \\
1\end{array}$} & \multirow{2}{*}{$\begin{array}{l}\text { Kyber } \\
\text { agresia } \\
591^{* *}\end{array}$} \\
\hline \multirow{3}{*}{ agresia } & $r$ & & & & & & \\
\hline & $\mathrm{p}$ & & ,000 & & ,000 & & ,000 \\
\hline & $\mathrm{n}$ & 213 & 212 & 165 & 165 & 378 & 377 \\
\hline \multirow{3}{*}{$\begin{array}{l}\text { kyber } \\
\text { agresia }\end{array}$} & $\mathrm{r}$ &, $655^{* * * *}$ & 1 &, $503^{* * *}$ & 1 & $591^{* * *}$ & 1 \\
\hline & $\mathrm{p}$ &, 000 & &, 000 & &, 000 & \\
\hline & $\mathrm{n}$ & 212 & 212 & 165 & 165 & 377 & 377 \\
\hline
\end{tabular}

Nepatrné rozdiely nastali u chlapcov, ktorých sa výskumu v roku 2009 zúčastnilo 213. Korelačný koeficient dosiahol hodnotu $r=0,655$, čo predstavuje vysokú koreláciu. Avšak v roku 2014 bol počet chlapcov nižší (n $165)$ v porovnaní s rokom 2009. Korelačný koeficient dosiahol hodnotu $r=$ 0,503 , čo je vysoká korelácia, v tomto prípade je to však vel'mi tesné. Sumárne pri počte 378 chlapcov bol koeficient 0,591 a upozorňoval na vysokú koreláciu. 


\section{Závery a diskusia}

Intenciou výskumu bolo zistit' a overit' mieru agresívneho správania žiakov vo vzt’ahu ku kybernetickej agresii. Nepreukázal sa významný štatistický rozdiel medzi pohlavím a agresiou. Tradičné predstavy l'udí v minulosti, ako aj dnes, podporujú názor o agresívnejšom správaní chlapcov v porovnaní $\mathrm{s}$ dievčatami. Výskum preukázal, že chlapci a dievčatá vykazovali štatisticky rovnakú mieru agresie. V súčasnosti sa stierajú rozdiely medzi agresívnymi prejavmi chlapcov a dievčat. Predkladáme niekol'ko argumentov daného zistenia. Do popredia sa dostáva sociálna a relačná forma agresie realizovaná v tradičných rovesníckych vzt'ahoch, ako aj v kyberprostredí. Podstatou relačnej a sociálnej agresie je správanie, ktoré má $\mathrm{v}$ úmysle poškodit' priatel'stvá, sociálny status osoby, sociálnu a sexuálnu povest' priatel'a, alebo pocity spolupatričnosti v určitej skupine rovesníkov. Do sociálnej a relačnej agresie možno zahrnút' kyberagresiu, vrátane kyberšikany, vylúčenie priatel'ov z rovesníckych a online skupín. Ide o typicky, „ženské“ prejavy správania, podporené anonymitou kyberprostredia v prípade kybernetických útokov. Ide o isté predikcie rovnakej miery agresie u chlapcov a dievčat, ktoré sa preukázali výskumným šetrením. Napokon to potvrdil aj vzt'ah medzi agresiou a kybernetickou agresiou meraný v rokoch 2009 a 2014, kde sa ukázala príčinná súvislost' medzi agresívnym správaním chlapcov a dievčat v sociálnom prostredí a ich útokmi v kyberprostredí a tolerovaní kyberagresie vrátane kyberšikany.

Zaujímavým zistením bola komparácia agresie žiakov vzhl’adom ku kraju, $\mathrm{z}$ ktorého respondenti pochádzali. Žiaci $\mathrm{v}$ trnavskom kraji preukazovali vyššiu mieru agresie na rozdiel od žiakov z banskobystrického a prešovského kraja. Štatisticky vysoko signifikantný rozdiel sa preukázal vo vyššej miere agresívneho správania žiakov trnavského kraja oproti žiakom trenčianskeho kraja. Taktiež žiaci banskobystrického a prešovského kraja vykazovali vyššiu mieru agresie oproti žiakom bratislavského a trenčianskeho kraja. Je zrejmé, že agresia žiakov stúpa. V jednotlivých krajoch sa preukázala rozličná miera agresie žiakov. Ked’že sme neskúmali geografické ukazovatele krajov, edukačné výsledky žiakov, sociálno-kultúrne a rodinné ukazovatele, domnievame sa, že uvedená ,agresívna premenlivost‘“ žiakov v jednotlivých krajoch má aj tieto kauzálne väzby.

Uvedená štúdia je východiskom pre mapovanie agresívneho správania, vrátane kyberagresie a kyberšikanovania vodmienkach Slovenskej republiky.

\section{Bibliography}

ADAMIK-SIMEGOVA, M. 2011. Vyskum psychologickych aspektov sikanovania u ziakov zakladnych skol. In Adamik-Simegova, M. Kovacova, B. 2011. Kognitivne, emocionalne a moralne aspekty skolskeho sikanovania a ich vyuzitie v prevencii sikanovania na zakladnej skole. Trnava : PF TU. ISBN 978-80-8082-420-4.

BUSS, A. H. - PERRY, M. 1992. The Aggression Questionnaire. Journal of Personality and Social Psychology 63. pp. 452-459.

GRICK, N. R. - GROTPETER, J. K. 1995. Relational aggression, gender, and social-psychological adjustment. Child Development, 66. pp. 710-722. 
HOLLA, K. 2013. Kybersikana. Bratislava: Iris.

HOLLA, K. - KURINCOVA, V. 2013. Manifestations of Aggressive Behaviour in Pupils - Theoretical Views and Research Findings. New Educational Review. ISSN 1732-6729, Vol. 34, no. 4 (2013), p. 111-122.

HRIVIKOVA, Z. 2013. Agresivne spravanie u ziakov zakladnych skol. In Zbornik vedecko-vyskumnych prac doktorandov Pedagogickej fakulty UMB. UMB: Banska Bystrica. ISBN 978-80-557-0658-0, pp. 55-67.

KRASCENICOVA, A. 2014. Vyskyt kybersikanovania medzi ziakmi na II. stupni ZS. Nitra: PF UKF. Diplomova praca.

LOVAS, L. 2010. Agresia a násilie. Bratislava: Ikar. ISBN 978-80-551-17522.

ONDREJKOVIC, P. et al. 2009. Socialna patologia. Bratislava: Veda. ISBN 9-788-0224-1074-8.

MARTINEK, Z. 2009. Agresivita a kriminalita školní mládeže. Praha: Grada. ISBN 978-80-247-2310-5.

PORNARI, CH. D. - WOOD, J. 2010. Peer a cyber aggression in secondary school students: the role of moral disengagement, hostile attribution bias, and outcome expectancies. Aggressive behavior. Vol. 36. No. 2. pp. 81-94 p. Available online: http://www.ncbi.nlm.nih.gov/pubmed/20035548

RICAN, P. 1999. Krutost jako prezit a jako motiv. Ceskoslovenska psychologie. Vol. 43. pp. 543-555.

RICAN, P. - JANOSOVA, P. 2010. Jak na sikanu. Praha: Grada. ISBN 97880-247-2991-6.

SCHOFFSTALL, C. L. - COHEN, R. 2011. Cyber Aggression: The Relation between Online Offenders and Offline Social Competence. Social Development. Vol. 20, No. 3, pp. 587-604

VALIMAKI, M. et al. 2012. Doporuceni k prevenci kybersikany ve skolnim prostredi: prehled a rady. Cyberpsychology.eu. Available online: www.cyberpsychology.eu/team/storage/COST-2012-cyberbullying-

Doporuceni_k_prevenci_kybersikany_ve_skolnim_prostredi_prehled_a_rady .pdf

Štúdia bola napísaná v rámci riešenia projektu KEGA 036UKF-4/2014 „Ovplyvňovanie agresívneho správania žiakov formovaním optimálnej klímy školy a triedy".

PaedDr. Katarína Hollá, PhD.

Constanine the Philosopher University

Faculty of Pedagogy, Department of Pedagogy

Dražovská cesta 4, 94974 Nitra

Slovakia

kholla@ukf.sk 